\title{
Pemodelan Matematika SIRI pada Penyebaran Penyakit Tifus di Sulawesi Selatan
}

\author{
Syafrudin Side ${ }^{1}$, Ahmad Zaki ${ }^{1}$, dan Sartika ${ }^{1, \text { a) }}$ \\ ${ }^{1}$ Jurusan Matematika FMIPA Universitas Negeri Makassar \\ a) syafruddin@unm.ac.id \\ b) ahmad.zaki@unm.ac.id \\ c) tikatika2398@gmail.com
}

\begin{abstract}
Abstrak. Penelitian ini bertujuan untuk membangun model penyebaran penyakit Tifus tipe SIRI (Susceptible-Infected-Recovered-Infected), dengan menambahkan asumsi bahwa manusia yang sembuh dapat kembali terinfeksi penyakit Tifus. Model ini di bagi menjadi 3 kelas yaitu rentan, terinfeksi dan sembuh. Adapun prosedur penelitian dilakukan melalui tahapan-tahapan: membangun model penyebaran penyakit Tifus tipe SIRI, Menguji Kestabilan titik kesetimbangan dan menentukan bilangan reproduksi dasar $R_{0}$, kemudian menerapkannya pada kasus Penyakit Tifus di Provinsi Sulawesi Selatan. Data yang digunakan dalam membangun model adalah jumlah penderita penyakit Tifus tahun 2018 dari Dinas Kesehatan Provinsi Sulawesi Selatan. Model matematika tipe SIRI digunakan untuk menentukan titik equilibrium. Berdasarkan hasil simulasi model SIRI diperoleh bilangan reproduksi dasar $\left(R_{0}\right)$ sebesar 0,000903 yang menandakan bahwa penyebaran penyakit Tifus di Provinsi Sulawesi Selatan pada tahun 2018 bukan kejadian luar biasa atau dapat dikatakan bahwa seseorang yang terinfeksi penyakit Tifus ini tidak menyebabkan orang lain terkenapenyakit yang sama, dengan kata lain tidak terjadi wabah pada populasi tersebut.
\end{abstract}

Kata kunci: Titik Equilibrium, Bilangan Reproduksi Dasar, Tifus, Model SIRI.

Abstract. The research aims to build a SIRI model of the Typhoid spread (Susceptible-Infected-RecoveredInfected) by adding assumption that people who are recovered might be infected again. This model is divided into three classes, namely, susceptible, infected and recovered. the research procedure is carried out through several stages: Building SIRI model for the spread of Typhoid, examining the stability of the equilibrium point and determining the basic reproduction number, and applying the model to Typhoid cases in South Sulawesi. The data is the number of Typhus patients in 2018 that was obtained from Health office of South Sulawesi Province. SIRI type mathematical models are used to determine the equilibrium point. Based on the simulation results of the SIRI model, the basic reproduction number is 0,000903 indicate that, indicating that the spread of Typhus in the Province of South Sulawesi in 2018 was not an extraordinary event or it can be said that someone who is infected with this Typhoid does not cause another person to contract the same disease, in other words there was no outbreak in that population.

Keywords: equilibrium Point, Basic Reproductive Number, Typhoid, SIRI Model. 


\section{PENDAHULUAN}

Pemodelan matematika adalah salah-satu bagian matematika yang merupakan pengembangan aljabar. Analisis dan persamaan diferensial, karena isi dari pemodelan matematika sebagian besar merupakan penerapan atau aplikasi di bidang tersebut (Side, 2014). Model matematika sekarang ini banyak digunakan dalam bidang kesehatan. Seperti model matematika untuk menganalisis penyebaran penyakit diantaranya ada model epidermi SIR (Susceptible-Infected-Recovered), SEIR (Susceptible-Exposed-Infected-Recovered), dan lainnya (Putra, 2011).

Dalam model matematika SIR, populasi dibagi menjadi tiga subpopulasi yaitu kelompok individu yang rentan penyakit (S), kelompok individu yang terinfeksi (I), kelompok individu yang telah sembuh dan kebal dari penyakit (R) (Rosdiana, 2015). Namun dalam model matematika SIRI Individu yang telah sembuh dapat kembali terinfeksi. Selain digunakan dibidang social model SIRI juga dapat digunakan dibidang kesehatan salah satunya untuk melihat tingkat penyebaran penyakit Tifus.

Penyakit demam Tifus merupakan suatu penyakit infeksi sistemik bersifat akut yang disebebkan oleh Salmonella Typhi. Insiden demam Tifus ditiap daerah bervariasi dan biasanya terkait dengan sanitasi lingkungan. Penyakit ini sangat cepat penularannya melalui pembuangan air, kotoran yang tidak memenuhi syarat dan kondisi saniter yang tidak sehat merupakan faktor terbesar terjadinya penyakit infeksi ini (Suhaemi, 2010).

Di indonesia khususnya Sulawesi Selatan, demam Tifus merupakan salah-satu dari penyakit infeksi terpenting. Penyakit ini endemik di seluruh daerah di provinsi ini dan merupakan penyakit infeksi terbanyak keempat yang dilaporkan dari 24 kabupaten. Di Sulawesi Selatan, Tifus merupakan penyebab terpenting terjadinya septis atau yang dapat menyebabkan berbagai perubahan yang merusak beberapa system organ, terkadang bahkan mengakibatkan kematian terkait komunitas, dengan insiden rate (jumlah kasus baru penyakit tertentu yang dilaporkan pada periode waktu dan tempat tertentu dibagi dengan jumlah penduduk dimana penyakit tersebut berjangkit) yang dilaporkan melebihi 2500/100.000 penduduk (Suhaemi, 2010).

Saat ini sudah banyak penelitian yang dilakukan dalam pemodelan matematika, baik itu pemodelan matematika SIR pada penyebaran penyakit tuberkulosis oleh Side (2015) memperhatikan transmisi dari populasi. Hasrina (2015) diperoleh hasil bahwa semakin besar laju penularan suatu penyakit mengakibatkan populasi pada kelas infected mengalami peningkatan yang menyebabkan populasi pada kelas susceptible mengalami penurunan. Rosdiana (2015) Pada kasus ini vaksinasi tidak mengobati penyakit hepatitis B melainkan mencegah agar individu tidak berperan dalam proses penyembuhan penyakit hepatitis B. Sedangkan penelitian untuk penyebaran penyakit Tifus sudah dilakukan oleh Suhaemi (2010) menjelaskan bahwa ada hubungan antara pengetahuan dengan kejadian demam Tifus di rumah sakit umum daerah Syekh yusuf kabupaten Gowa.

Pada penelitian ini menjelaskan mengenai modifikasi model yang telah dilakukan oleh Side dkk, menjadi model SIRI dengan menambahkan parameter laju individu yang kembali terinfeksi setelah sembuh dari penyakit Tifus. Hasil simulasi menggunakan data penderita penyakit Tifus yaitu semakin besar laju kesembuhan suatu penyakit mengakibatkan populasi pada kelas infected mengalami penurunan yang menyebabkan populasi pada kelas recovered semakin meningkat serta kelas susceptible semakin menurun. 


\section{KAJIAN PUSTAKA}

\section{Persamaan diferensial}

Persamaan diferensial banyak muncul sebagai persamaan yang penting dalam matematika terapan, karena banyak hukum dan hubungan fisis secara matematis muncul dalam bentuk persamaan ini. Secara umum persamaan diferensial didefinisikan. (Rahardi, dkk 2003).

\section{Definisi 1 (Rahardi, dkk 2003)}

Persamaan diferensial adalah suatu persamaan yang memuat satu atau lebih turunan dari suatu fungsiyang tak diketahui. Contoh persamaan diferensial biasa disajikan pada persamaan (1).

$$
\frac{d y}{d x}+2 y=2 x^{3}
$$

\section{Titik Tetap}

Misalkan diberikan persamaans diferensial sebagai berikut:

$$
\frac{d x}{d t}=f(x), x \in R^{n}
$$

Titik $x^{*}$ disebut titik tetap jika memenuhi $f\left(x^{*}\right)=0$. Titik tetap merupakan penyelesaian yang tidak bergantung pada $t$ (konstan terhadap waktu). Titik tetap disebut juga titik kritis atau titik kesetimbangan. Untuk selanjutnya akan digunakan titik tetap (Grimshaw, 1990).

\section{Kriteria Kestabilan Routh-Hurwits}

Permasalahan yang sering timbul dalam menentukan suatu tipe kestabilan sistem dengan menggunakan nilai eigen adalah ketika mencari akar persamaan karakteristik berorde tinggi. Oleh sebab itu, diperlukan suatu kriteria yang mampu menjamin nilai dari akar suatu persamaan karakteristik tersebut negatif atau ada yang bernilai positif. Salah-satu kriteria Routh-Hurwitz. (Wahab \& Subiatoro, 2004).

1. Persamaan polinom orde $n$ ditulis dalam bentuk sebagai berikut :

Dimana :

$$
a_{0} s^{n}+a_{1} s^{n-1}+a_{2} s^{n-2}+\cdots+a_{n-1} s+a_{n}=0
$$

$a_{0}, a_{1}, a_{2}, \cdots, a_{n}$ adalah koefisien dari persamaan tersebut dan $a_{n} \neq 0$ $s^{n}, s^{n-1}, s^{n-2}, \cdots, s^{0}$ adalah label

2. Bila ada koefisien yang bernilai 0 atau negatif disamping adanya koefisien positif, maka hal ini menunjukka ada satu akar atau akar-akar imajiner atau memiliki bagian real positif (sistem tak stabil). Kondisi perlu (tetapi belum cukup) untuk stabil adalah semua kosefisien persamaan polinom positif dan lengkap.

3. Bila semua koefisien positif, buat tabel Routh-Hurwitz seperti ditunjukkan pada tabel 1 .

TABEL 1. Rount-Hurwitz

\begin{tabular}{ccccccc}
\hline $\boldsymbol{s}^{\boldsymbol{n}}$ & $\boldsymbol{a}_{\mathbf{0}}$ & $\boldsymbol{a}_{\mathbf{2}}$ & $\boldsymbol{a}_{\mathbf{4}}$ & $\boldsymbol{a}_{\mathbf{6}}$ & $\ldots$ & $\boldsymbol{a}_{\boldsymbol{n}-\mathbf{1}}$ \\
\hline$s^{n-1}$ & $a_{1}$ & $a_{3}$ & $a_{5}$ & $a_{7}$ & $\ldots$ & $a_{n}$ \\
$s^{n-2}$ & $b_{1}$ & $b_{2}$ & $b_{3}$ & $b_{4}$ & $\ldots$ & $b_{n}$ \\
$s^{n-3}$ & $c_{1}$ & $c_{2}$ & $c_{3}$ & $c_{4}$ & $\ldots$ & $c_{n}$ \\
$\vdots$ & $\vdots$ & $\vdots$ & & & & \\
$s^{0}$ & & & & & & \\
\hline
\end{tabular}

(Wahab \& Subiantoro, 2004) 


\section{Bilangan Reproduksi Dasar}

Bilangan reproduksi dasar merupakan bilangan yang menunjukkan jumlah individu rentan yang dapat menderita penyakit yang disebabkan oleh satu individu terinfeksi. Bilangan reproduksi dasar dilambangkan dengan $R_{0}$. Bilangan tersebut diperlukan sebagai parameter untuk mengetahui tingkat penyebaran suatu penyakit. Bilangan reproduksi dasar diperoleh dengan menggunakan nilai eigen dari matriks jacobian dari suatu sistem persamaan (model) yang dihitung pada titik bebas penyakit. (Fitrianah, 2015).

Ada beberapa kondisi yang akan timbul dalam penentuan $R_{0}$, yaitu:

1. Jika $R_{0}<1$, maka penyakit akan menghilang.

2. Jika $R_{0}=1$, maka penyakit akan menetap.

3. Jika $R_{0}>1$, maka penyakit akan meningkat menjadi wabah (Fitrianah, 2015).

\section{METODE PENELITIAN}

Jenis penelitian yang digunakan adalah kajian teori dan terapan/aplikasi, yaitu penelitian yang bertujuan untuk menyelesaikan masalah-masalah yang ada berdasarkan asumsi yang telah dibuat. Objek kajian pada penelitian ini yaitu pasien penderita penyakit Tifus di Sulawesi Selatan.

Adapun langkah-langkah yang dilakukan dalam penelitian ini adalah sebagai berikut:

1. Membangun model matematika penyebaran penyakit Tifus dengan menggunakan model SIRI di Kota Makassar.

a. Mengumpulkan informasi dan data yang terkait model SIRI pada penyebaran penyakit Tifus.

b. Menentukan model SIRI dengan memperhatikan diagram alur yang telah di buat.

2. Menganalisis kestabilan model SIRI pada penyebaran penyakit Tifus di Sulawesi Selatan.

a. Menentukan titik tetap model SIRI yang telah dibuat, yaitu titik tetap bebas penyakit dan titik tetap endemik penyakit.

b. Menganalisis kestabilan titik tetap bebas penyakit dan titik tetap endemik penyakit SIRI berdasarkan tabel rount-hurwitz.

c. Menentukan bilangan reproduksi dasar dari model SIRI.

3. Mengetahui bagaimana penyebaran penyakit penyakit Tifus di Sulawesi Selatan menggunakan simulasi dari model SIRI.

a. Menentukan nilai awal yang diperoleh dari Dinas Kesehatan Kota Makassar pada hasil pemodelan SIRI.

b. Simulai program dengan nilai-nilai yang telah diperoleh.

c. Menarik kesimpulan dari hasil simulasi model SIRI.

\section{HASIL PENELITIAN}

\section{Formulasi Model}

Pada model ini, populasi total $(\mathrm{N})$ dibagi menjadi 3 kelas yaitu, kelas Susceptible $(\mathrm{S}(\mathrm{t}))$ menyatakan kelas yang rentan terhadap penyakit Tifus, kelas infected $(\mathrm{I}(\mathrm{t}))$ menyatakan kelas yang terinfeksi, dan kelas Recovered $(\mathrm{R}(\mathrm{t}))$ menyatakan kelas yang telah sembuh dari penyakit Tifus. 
Dalam penelitian ini terdapat beberapa asumsi yang digunakan untuk memodelkan penyebaran penyakit Tifus (Haslinda, 2016)

1. Terdapat kelahiran dan kematian dalam suatu populasi.

2. Setiap individu yang lahir akan menjadi rentan.

3. Setiap individu yang terdeteksi akan menjadi terinfeksi.

4. Masa inkubasi penyakit Tifus (singkat) 7-21 hari.

5. Penyakit berbahaya, jika terinfeksi dapat menimbulkan kematian.

6. Individu yang telah sembuh dapat kembali terinfeksi karena kurang menjaga kesehatan. Bakteri yang ada dalam tubuh belum sepenuhnya mati tapi dalam kondisi dorman aktif ketika sistem kekebalan tubuh menurun maka bakteri tersebut bisa aktif kembali sehingga akan kembali terkena penyakit Tifus. Salah satu faktor yang menyebabkan imunitas (sistem kekebalan tubuh) menurun adalah kurangnya istirahat atau kecapean.

Berdasarkan asumsi diatas maka diperoleh model SIRI untuk penyebaran penyakit Tifus dalam bentuk diagram transfer yang dapat dilihat pada gambar 1 .

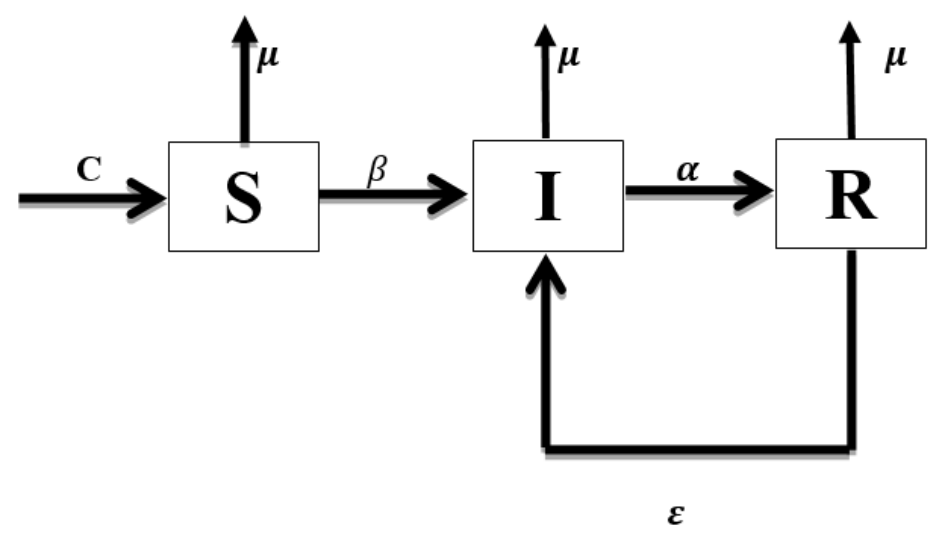

GAMBAR 1. Diagram Transfer Model SIRI pada Penyebaran Penyakit Tifus

Keterangan:

$S(t) \quad$ : Jumlah individu yang rentan dalam populasi pada waktu $\mathrm{t}$

$I(t) \quad$ : Jumlah individu yang terinfeksi dalam populasi pada waktu $\mathrm{t}$

$R(t) \quad$ : Jumlah individu yang sembuh dalam populasi pada waktu $\mathrm{t}$

$C \quad$ : Laju kelahiran

$\mu \quad$ : Laju kematian alami

$\beta \quad$ : Laju penularan penyakit

$\alpha \quad$ : Laju kesembuhan penyakit

$\varepsilon \quad$ : Laju individu yang kembali terinfeksi

Berdasarkan asumsi dan hubungan antara variabel dan parameter pada Gambar 1. dapat dijelaskan pada persamaan berikut

$$
\begin{aligned}
& \frac{d S}{d t}=C-(\mu+\beta) S \\
& \frac{d I}{d t}=\beta S+\varepsilon R-(\mu+\alpha) I \\
& \frac{d R}{d t}=\alpha I-(\mu+\varepsilon) R
\end{aligned}
$$

Dengan $N \neq(S(t)+I(t)+R(t))$. 


\section{Analisis Model Matematika SIRI Penyebaran Penyakit Tifus}

\section{Titik Equilibrium Bebas Penyakit $\left(E_{0}\right)$}

Titik equilibrium bebas penyakit adalah suatu keadaan dimana tidak terjadi penyebaran penyakit menular dalam populasi. Titik equilibrium pada persamaan (3) terjadi pada saat $\left(\frac{d s}{d t}, \frac{d i}{d t}, \frac{d r}{d t}\right)=$ $(0,0,0)$. Berdasarkan persamaan (3) dapat ditentukan titik equilibrium bebas penyakit dengan menolkan ruas kanan persamaan sehingga diperoleh persamaan (4).

$$
\begin{aligned}
& C-(\mu+\beta) S \\
& \beta S+\varepsilon R-(\mu+\alpha) I \\
& \alpha I-(\mu+\varepsilon) R
\end{aligned}
$$

Untuk mengetahui titik equilibrium bebas penyakit $\left(E_{0}\right)$ maka diasumsikan $\mathrm{i}=0$, maka haruslah $\beta=0$ yang berarti tidak ada individu yang terinfeksi. Dari persamaan (4) diperoleh titik equilibrium berikut.

$$
\begin{aligned}
& \text { 1) } C-(\mu+\beta) S=0 \\
& (\mu+\beta) S=C \\
& S=\frac{C}{\mu} \\
& \text { 2) } \alpha I-(\mu+\varepsilon) R=0 \\
& 0(\mu+\varepsilon) R=0 \\
& R=\frac{0}{(\mu+\varepsilon)} \\
& R=0
\end{aligned}
$$

Jadi titik equilibrium bebas penyakit $E_{0}=\left(\frac{C}{\mu}, 0,0\right)$

\section{Titik Equilibrium Endemik $\left(E_{1}\right)$}

Titik equilibrium endemik adalah suatu keadaan dimana terjadi penyebaran penyakit menular didalam populasi tersebut. Untuk mengetahui titik equilibrium endemik, dimisalkan $E_{1}\left(s^{*}, i^{*}, r^{*}\right)$ dan dapat diketahui dengan mengasumsikan $\mathrm{i} \neq 0$. Untuk menentukan titik equilibrium endemik diperoleh dengan menolkan ruas kanan pada persamaan (3). sehingga turunan pertamanya bernilai nol. Maka akan diperoleh persamaan (5).

$$
\begin{aligned}
& C-(\mu+\beta) S=0 \\
& \beta S+\varepsilon R-(\mu+\alpha) I=0 \\
& \alpha I-(\mu+\varepsilon) R=0
\end{aligned}
$$

Jadi titik equilibrium endemiknya adalah

$$
E_{1}\left(\frac{C}{\mu+\beta}, \frac{\beta c(\mu+\varepsilon)}{\mu\left(\mu^{2}+\mu \alpha+\mu \varepsilon+\mu \beta+\alpha \beta+\beta \varepsilon\right)}, \frac{\alpha \beta C}{\mu\left(\mu^{2}+\mu \varepsilon+\mu \alpha+\mu \beta+\beta \varepsilon+\alpha \beta\right)}\right)
$$

Analisis kestabilan titik equilibrium

Matriks jacobian dari titik equilibrium bebas penyakit.

$$
J E_{0}=\left[\begin{array}{ccc}
-(\mu+\beta) & 0 & 0 \\
\beta & -(\mu+\alpha) & \varepsilon \\
0 & \alpha & -(\mu+\varepsilon)
\end{array}\right]
$$


Untuk mengetahui kestabilan $E_{0}$ maka terlebih dahulu dicari nilai eigennya. Jika $\lambda_{i}$ adalah nilai eigen dari $J E_{0}$ maka

$\operatorname{det} \lambda I-J E_{0}=0$

$\operatorname{det}\left(\lambda\left[\begin{array}{lll}1 & 0 & 0 \\ 0 & 1 & 0 \\ 0 & 0 & 1\end{array}\right]-\left[\begin{array}{ccc}-(\mu+\beta) & 0 & 0 \\ \beta & -(\mu+\alpha) & \varepsilon \\ 0 & \alpha & -(\mu+\varepsilon)\end{array}\right]\right)=0$
$\operatorname{det}\left(\left[\begin{array}{lll}\lambda & 0 & 0 \\ 0 & \lambda & 0 \\ 0 & 0 & \lambda\end{array}\right]-\left[\begin{array}{ccc}-(\mu+\beta) & 0 & 0 \\ \beta & -(\mu+\alpha) & \varepsilon \\ 0 & \alpha & -(\mu+\varepsilon)\end{array}\right]\right)=0$

$\operatorname{det}\left(\left[\begin{array}{ccc}(\lambda+\mu+\beta) & 0 & 0 \\ -\beta & (\lambda+\mu+\alpha) & -\varepsilon \\ 0 & -\alpha & (\lambda+\mu+\varepsilon)\end{array}\right]\right)=0$

$=((\lambda+\mu+\beta)(\lambda+\mu+\alpha)(\lambda+\mu+\varepsilon))+(0 .(-\varepsilon) .0)+(0 .(-\beta)(-\alpha)-(0(\lambda+\mu+$

$\alpha) .0)-((\lambda+\mu+\beta)(-\varepsilon)(-\alpha))-(0(-\beta)(\lambda+\mu+\varepsilon))$

$=((\lambda+\mu+\beta)(\lambda+\mu+\alpha)(\lambda+\mu+\varepsilon))+0+0-0-(\lambda+\mu+\beta)(-\varepsilon)(-\alpha))-0$

$=\left(\lambda^{2}+\lambda \mu+\lambda \alpha+\mu \lambda+\mu^{2}+\mu \alpha+\beta \lambda+\beta \mu+\beta \alpha\right)(\lambda+\mu+\varepsilon)$

$=\left(\lambda^{3}+\lambda^{2} \mu+\lambda^{2} \varepsilon+\lambda^{2} \mu+\lambda \mu^{2}+\lambda \mu \varepsilon+\lambda^{2} \alpha+\lambda \alpha \mu+\lambda \alpha \varepsilon+\lambda^{2} \mu+\mu^{2} \lambda+\mu \lambda \varepsilon+\mu^{2} \lambda+\right.$ $\mu^{3}+\mu^{2} \varepsilon+\mu \alpha \lambda+\mu^{2} \alpha+\mu \alpha \varepsilon+\beta \lambda^{2}+\beta \lambda \mu+\beta \lambda \varepsilon+\beta \mu \lambda+\beta \mu^{2}+\beta \mu \varepsilon+\beta \alpha \lambda+$

$\beta \alpha \mu+\beta \alpha \varepsilon-\lambda \varepsilon \alpha-\mu \varepsilon \alpha-\beta \varepsilon \alpha)$

$=\left(\lambda^{3}+3\left(\lambda^{2} \mu\right)+\lambda^{2} \varepsilon+3\left(\lambda \mu^{2}\right)+2(\lambda \mu \varepsilon)+\lambda^{2} \alpha+2(\lambda \alpha \mu)+\mu^{3}+\mu^{2} \varepsilon+\mu^{2} \alpha+\beta \lambda^{2}+\right.$

$\left.2(\beta \lambda \mu)+\beta \lambda \varepsilon+\beta \mu^{2}+\beta \mu \varepsilon+\beta \alpha \lambda+\beta \alpha \mu+\beta \varepsilon \alpha\right)$

Persamaan diatas dapat ditulis menjadi persamaan (8).

$$
\lambda^{3}+\alpha \lambda^{2}+b \lambda+c=0
$$

Misalkan:

$\mathrm{a}=(3 \mu+\varepsilon+\alpha+\beta)$

$\mathrm{b}=\left(3 \mu^{2}+2 \mu \varepsilon+2 \alpha \mu+2 \beta \mu+\beta \varepsilon+\beta \alpha\right)$

$\mathrm{c}=\left(\mu^{3}+\mu^{2} \varepsilon+\mu^{2} \alpha+\beta \mu^{2}+\beta \mu \varepsilon+\beta \alpha \mu\right)$

untuk polynomial orde tiga, analisis kestabilannya menggunakan kriteria Routh-Hurwitz.

Sehingga dapat di buat tabel Routh-Hurwitz sebagaimana tabel 2

TABEL 2. Routh-Hurwitz

\begin{tabular}{cccc}
\hline$\lambda^{3}$ & 1 & $\mathrm{~B}$ & 0 \\
\hline$\lambda^{2}$ & $\mathrm{~A}$ & $\mathrm{C}$ & 0 \\
$\lambda^{1}$ & $\frac{a b-c}{a}$ & 0 & 0 \\
$\lambda^{0}$ & $\frac{a b c-c^{2}}{a b-c}$ & 0 & 0 \\
\hline
\end{tabular}

Suatu sistem dikatakan stabil, jika semua suku pada kolom pertama tabel routh Hurwitz bertanda positif. Karena semua suku positif maka sistem tersebut stabil.

\section{Bilangan Reproduksi Dasar}

Bilangan reproduksi dasar dari penyakit Tifus diperoleh dengan menentukan nilai eigen dari matriks jacobian dari suatu sistem persamaan yang dihitung pada titik equilibrium bebas penyakit.

Nilai reproduksi dasar dari persamaan diatas diperoleh dari bagian konstannya, sehingga diperoleh: 


$$
\begin{gathered}
\boldsymbol{\mu}^{3}+\boldsymbol{\mu}^{2} \varepsilon+\boldsymbol{\mu}^{2} \boldsymbol{\alpha}+\boldsymbol{\beta} \boldsymbol{\mu}^{2}+\boldsymbol{\beta} \boldsymbol{\mu} \varepsilon+\boldsymbol{\beta} \boldsymbol{\alpha} \boldsymbol{\mu}=\mathbf{0} \\
R_{0}=\mu^{3}+\mu^{2} \varepsilon+\mu^{2} \alpha+\beta \mu^{2}+\beta \mu \varepsilon+\beta \alpha \mu
\end{gathered}
$$

\section{Simulasi Model}

Simulasi dilakukan menggunakan nilai awal yang disajikan pada TABEL 3.

\begin{tabular}{|c|c|c|c|}
\hline \multirow{2}{*}{ Variabel } & \multicolumn{3}{|c|}{ Nilai Awal } \\
\hline & $10 \%$ & $50 \%$ & $90 \%$ \\
\hline \multirow{2}{*}{$S(0)$} & 36158 & 36158 & 36158 \\
\hline & $\overline{8612931}$ & $\overline{8612931}$ & $\overline{8612931}$ \\
\hline \multirow{2}{*}{$\mathrm{I}(0)$} & 33165 & 33165 & 33165 \\
\hline & 8612931 & 8612931 & 8612931 \\
\hline \multirow{2}{*}{$\mathrm{R}(0)$} & 3347 & 16733 & 30119 \\
\hline & $\overline{8612931}$ & $\overline{8612931}$ & $\overline{8612931}$ \\
\hline
\end{tabular}

TABEL 3. Data awal

Parameter-parameter yang digunakan dalam model ini dapat dilihat pada TABEL 4. sebagai berikut

TABEL 4. Parameter model SIRI penyakit Tifus

\begin{tabular}{cc}
\hline Parameter & Formulasi \\
\hline$C$ & 0,041 \\
$C$ & 0,034 \\
$C$ & 0,030 \\
$\beta$ & 0,9 \\
$\mu$ & 0,041 \\
$\mu$ & 0,034 \\
$\mu$ & 0,030 \\
$\alpha$ & 0,1 \\
$\alpha$ & 0,5 \\
$\alpha$ & 0,9 \\
$\varepsilon$ & 0,5 \\
\hline
\end{tabular}

Simulasi Model SIRI Menggunakan sofware

Simulasi model disajikan pada GAMBAR 2.

1. Simulasi untuk populasi susceptible, infected dan recovered dengan nilai $\mathrm{R}$ sebesar $10 \%$ dari jumlah populasi yang terinfeksi.

GAMBAR 2 menunjukkan simulasi jumlah individu rentan terkena penyakit Tifus konstan disetiap bulannya. Adapun jumlah infected mengalami kenaikan secara drastis dari bulan pertama hingga bulan ke-120. Terdapat $80 \%$ individu yang terinfeksi penyakit Tifus atau sama dengan 6.890.345 jiwa dari total populasi sebanyak 8.612.931 jiwa. Nilai $80 \%$ tersebut diperoleh dari hasil pembagian antara individu yang terinfeksi dengan total populasi. Selanjutnya untuk individu yang sembuh juga mengalami peningkatan dari bulan pertama hingga bulan ke 120 . Terdapat $15 \%$ individu yang yang sembuh dari penyakit Tifus atau sama dengan 1.291.940 jiwa dari total populasi sebanyak 8.612.931 jiwa 


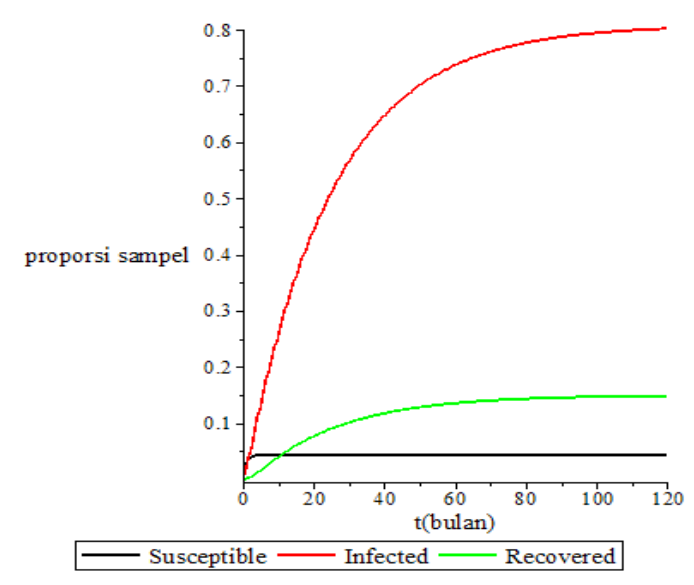

GAMBAR 2. Kurva Model Penyakit Tifus

2. Simulasi untuk populasi susceptible, infected dan recovered dengan nilai $\mathrm{R}$ sebesar $50 \%$ dari jumlah populasi yang terinfeksi.

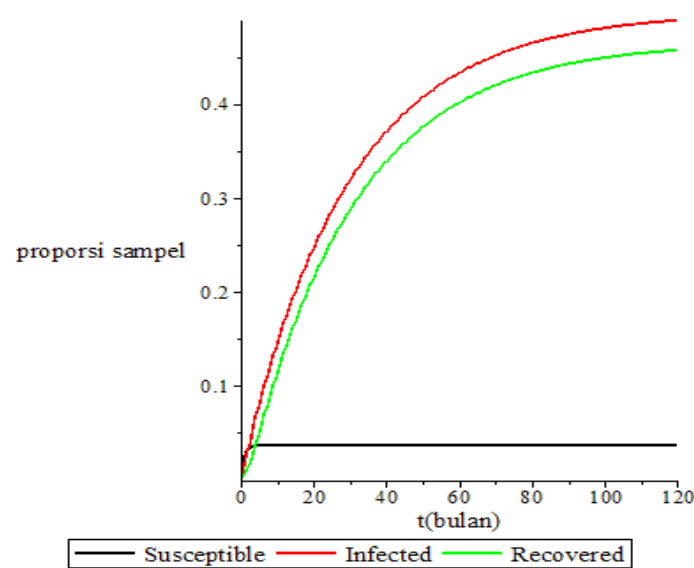

GAMBAR 3. Kurva Model Penyakit Tifus

GAMBAR 3 menunjukkan simulasi jumlah individu rentan terkena penyakit Tifus konstan disetiap bulannya. Adapun jumlah infected mengalami kenaikan secara drastis dari bulan pertama hingga bulan ke-120 dan pada. Terdapat 49\% individu yang terinfeksi dari penyakit Tifus atau sama dengan 4.220.337 jiwa dari total populasi sebanyak 8.612.931. Nilai $49 \%$ tersebut diperoleh dari hasil pembagian antara individu yang terinfeksi dengan total populasi. Selanjutnya untuk individu yang sembuh juga mengalami peningkatan dari bulan pertama hingga bulan ke 120 . Terdapat $46 \%$ individu yang akan sembuh dari penyakit Tifus atau sama dengan 3.961.948 jiwa.

3. Simulasi untuk populasi susceptible, infected dan recovered dengan nilai R sebesar $90 \%$ dari jumlah populasi yang terinfeksi

GAMBAR 4 menunjukkan simulasi jumlah individu rentan terkena penyakit Tifus konstan disetiap bulannya. Adapun jumlah infected mengalami kenaikan secara drastis dari bulan pertama hingga bulan ke-120. Terdapat $35 \%$ individu yang terinfeksi atau sama dengan 3.014.523 dari jumlah populasi sebanyak 8.612.391. Nilai 35\% tersebut diperoleh dari hasil pembagian antara individu yang terinfeksi dengan total populasi. Selanjutnya untuk individu yang sembuh juga mengalami peningkatan dari bulan pertama hingga bulan ke 120. Terdapat $58 \%$ individu yang akan sembuh dari penyakit Tifus atau sama dengan 4.995 .500 jiwa. 


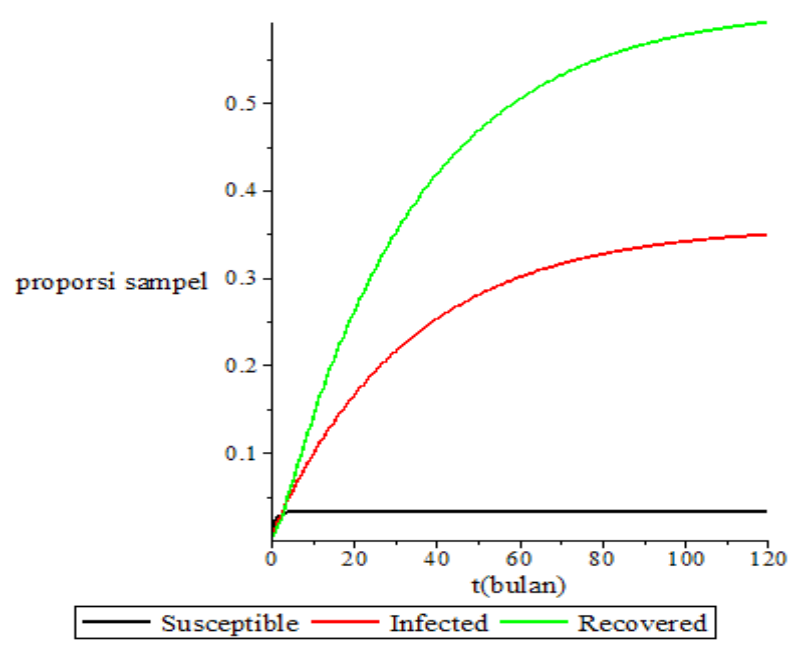

GAMBAR 4. Kurva Model Penyakit Tifus

\section{KESIMPULAN}

Berdasarkan hasil penelitian yang telah diuraikan, diperoleh kesimpulan sebagai berikut.

Analisis kestabilan bilangan reproduksi dasar $\left(R_{0}\right)$ model SIRI pada penyebaran penyakit Tifus di Provinsi Sulawesi Selatan diperoleh nilai $\left(R_{0}\right)$ sebanyak tiga yaitu sebesar 0.02473042 , 0,032835704 dan 0,039897000 . Dari ketiga nilai $\left(R_{0}\right)$ tersebut semuanya lebih kecil dari 1 yang berarti bahwa seseorang yang terinfeksi penyakit Tifus tidak menyebabkan orang lain terkena penyakit Tifus.

Hasil simulasi numerik model SIRI pada penyebaran penyakit Tifus diperoleh diperoleh bahwa semakin besar laju kesembuhan suatu penyakit mengakibatkan populasi pada kelas infected mengalami penurunan yang menyebabkan populasi pada kelas recovered semakin meningkat serta kelas susceptible semakin menurun.

\section{DAFTAR PUSTAKA}

Fitrianah, A. (2015). Analisis Dinamika Model Penyebaran Penyakit Kolera. Departement Matematika Fakultas dan Ilmu Pengetahuan Alam Istitut Pertanian Bogor, Bogor.

Grimshaw, R. (1990). Nonlinear Ordinarty Differential Equations. Blakwell Scientific Publicatio. Oxford Boston Melbourne.

Haslinda. (2016). Hubungan Personal Hygiene dan Kebiasaan Jajan Terhadap Kejadian Demam Typhoid Pada Anak (Skipsi). Makassar: Universitas Islam Negeri Alauddin.

Hasrina. (2015). Model SIR (Susceptible, Infectious, Recovered) pada Penyebarab Penyakit Tuberkolosis di Kota Makassar. Universitas Negeri Makassar, Makassar.

Putra, R. T. (2011). Kestabilan lokal bebas penyakit model epidemi SEIR dengan kumpulan infeksi pada periode laten, infeksi dan sembuh. Rekayasa Sipil, 7(1). 42-52.

Rahardi, dkk. 2003. Persamaan diferensial Biasa. JICA : Malang.

Rosdiana. (2015). Pemodelan Matematika SIR dengan Vaksinasi pada Penyebaran Penyakit Hepatitis B (Studi Kasu Provinsi Sulawesi Selatan). Universitas Negeri Makassar, Makassar. 
Side, S. 2014. Pemodelan matematika SIR dan SEIR. Badan penerbit UNM: Makassar.

Side, S. (2015). A Susceptible-Infected-Recovered Model and Simulation for Transmission of Tuberculosis. Jurnal American Scientific Publishers. 21(2). 137-139.

Suhaemi. 2010. Faktor-Faktor yang berhubungan dengan Kejadian Demam Tyfoid di RSUD Syekh Yusuf Kab. Gowa. Universitas Negeri Makassar, Makassar.

Wahab, W. \& Subiantoro, A. (2004). Fundamental of Control system Stability Criteria routhhurwiz 